\title{
Keterpaduan Komponen Pengembangan Pariwisata Kotagede SEbagai KaWASAN Wisata BUdAYa BerkelanJutan
}

\author{
NIRMANA ADHELIA \\ PROGRAM STUdi PERENCANAAN WILAYAH DAN KotA, \\ JURUSAN ARSITEKTUR, FAKULTAS TEKNIK \\ UNIVERSITAS SEBELAS MARET, SURAKARTA \\ SOEDWIWAHJONO \\ PROGRAM STUdi PERENCANAAN WILAYAH DAN KotA, \\ JURUSAN ARSITEKTUR, FAKULTAS TEKNIK \\ UNIVERSITAS SEBELAS MARET, SURAKARTA \\ GALING YUDANA \\ Program STUdi PERENCANAAN WILAYAH DAN KotA, \\ JURUSAN ARSITEKTUR, FAKULTAS TEKNIK \\ UNIVERSITAS SEBELAS MARET, SURAKARTA
}

\begin{abstract}
Kotagede as the capital city of the former Mataram Islam kingdom has potential culture and history tourism which places in two different areas, Yogyakarta City and Bantul region. It needs contribution between Yogyakarta government, local government and local communities to protect Kotagede. The development of tourism activities also need support from all stakeholder to make the tourism sustain. Therefore, this research was conducted to determine the level of integration of tourism development components as the area of sustainable cultural tourism in Kotagede. The method of research is deductive-quantitative, while the data analisys technique used is descriptive analysis of quantitative, scoring and crosstab analysis. Results from this study is Kotagede judged to have met the criteria as a sustainable cultural tourism area with an integrated component of tourism development. However, when viewed from the stakeholder cooperation that occurred in the development of tourist areas, Kotagede showed a low value. Thus, although the components of tourism development Kotagede shows the alignment of sustainability, but the resulting relationship is still weak.
\end{abstract}

Keywords:cultural tourism area, integrated tourism, sustainable tourism, tourism

\section{PENDAHULUAN}

Sektor pariwisata merupakan salah satu sektor yang memiliki peran penting dalam perkembangan sebuah kota maupun wilayah. Banyak wilayah yang maju dengan didukung oleh pariwisatanya yang berkembang, diantaranya adalah D.I.Yogyakarta.Salah satu obyek wisata budaya di D.I.Yogyakarta yang perlu dikembangkan dan dimanfaatkan potensinya berada di Kawasan Kotagede.

Kawasan ini memiliki potensi wisata berbasis budaya dan sejarah sebagai daya tarik dalam merespon motivasi wisatawan. Potensi wisata tersebut diantaranya adalah wisata spiritual, wisata arsitektur, dan wisata belanja. Potensi-potensi wisata ini terletak di Kelurahan Prenggan, Kelurahan Purbayan, dan Desa Jagalan.

Melihat potensi yang dimiliki oleh Kotagede, sudah selayaknya bahwa kawasan tersebut harus terus dijaga dan dilestarikan. Kerjasama antara pemerintah D.I.Yogyakarta, pemerintah daerah (Kota Yogyakarta dan Kabupaten Bantul)serta masyarakat Kotagede menjadi hal yang sangat penting dalam menjaga kawasan ini.

Perkembangan kondisi wisata Kotagede saat ini mengalami kejenuhan dan bertolak belakang dengan 
kemajuan pariwisata daerah bagian lain D.I.Yogyakarta. Atraksi budaya yang ada di Kotagede dianggap kurang bervariasi, sehingga wisatawan lebih tertarik dengan objek wisata budaya yang lain. Upaya sebagai langkah menerapkan konsep keberlanjutan kepariwisataan, salah satunya dalam pelestarian pusaka tangible telah dilakukan oleh cendekiawan dan pemerhati bangunan bersejarah, begitu pula dengan industri kerajinan perak yang diberikan inovasi baru dalam berproduksi. Selain itu, masyarakat lokal pun ikut serta berpartisipasi dalam melakukan promosi wisata. Namun upaya-upaya tersebut belum mampu meningkatkan perkembangan wisata di Kotagede.

Rencana penataan Kawasan Kotagede sudah dimulai sejak tahun 2009 oleh Pemerintah D.I.Yogyakarta, Pemerintah Kota Yogyakarta dan Pemerintah Kabupaten Bantul. Hingga saat ini program perencanaan yang telah dilakukan oleh pemerintah berfokus pada kebijakan pungutan pajak, sedangkan agenda revitalisasi utama belum menjadi prioritas. Sementara itu dari sisi ekonomi, interaksi antara ekonomi dengan faktor-faktor kultural mengakibatkan munculnya identitas baru dan menonjol di Kotagede sebagai kota kerajinan perak. Hal ini merefleksikan bahwa kepentingan ekonomi lebih kuat dibandingkan dengan kepentingan budaya dalam interaksi keduanya. Sedangkan dari sisi sosial budaya, masyarakat mulai bekerjasama dengan komunitaskomunitas yang ada di Kotagede untuk mempertahankan nilai-nilai historis dan budaya yang terkandung didalamnya.

Dari pernyataan di atasmenunjukkan bahwa keterpaduan antara aspek-aspek yang mempengaruhi kegiatan kepariwisataan Kotagede belum terintegrasi dengan baik.Kurangnya kerjasama antar stakeholder ini juga ditunjukkan dengan adanya perbedaan keinginan antara pemerintah dengan masyarakat Kotagede. Terbentuknya program "Jogja Heritage City" sebagai upaya pemerintah provinsi dalam mewujudkan visi kepariwisataan Yogyakarta ini mendapatkan sambutan positif dari pemerintah daerah dan pelaku usaha, namun bertolak belakang dengan keinginan masyarakat yang tidak menginginkan Kotagede menjadi mass tourism.

Mengacu pada hal diatas, maka tujuan penelitian ini adalah untuk mengetahui tingkat keterpaduan komponen pegembangan pariwisata di Kotagede sebagai kawasan wisata budaya yang berkelanjutan. Oleh karena itu, didapatkan rumusan permasalahan dalam penelitian ini adalah bagaimanakah tingkat keterpaduan dalam komponen pengembangan pariwisata Kotagede sebagai kawasan wisata budaya yang berkelanjutan?

\section{METODE PENELITIAN}

Penelitian ini merupakan penelitian deskriptif dengan menggunakan pendekatan deduktif dimana dalam merumuskan variabel menggunakan teori, sehingga diketahui kebutuhan data yang akan digunakan.Penelitian ini termasuk dalam penelitian studi kasus yang merupakan strategi penelitian dimana menurut Stake dalam Creswell (2010) didalamnya peneliti menyelidiki secara cermat suatu program, peristiwa, kegiatan, proses atau sekelompok individu pada kondisi tertentu.

Keterpaduan dalam penelitian ini terkaitkesatuan antara stakeholder dan komponen pariwisata yang terjadidalam pengembangan kawasan wisata. Sedangkan keberlanjutan yang di maksud berkaitan dengan konsep pelestarian, yaitu perlindungan, pengembangan, dan pemanfaatan kawasan yang dilihat berdasarkan kerjasama antar stakeholder.

Pengumpulan data yang dibutuhkan dalam penelitian terbagi menjadi data 
primer dan data sekunder. Data primer didapatkan melalui observasi lapangan, wawancara dan kuesioner serta data sekunder didapatkan melalui studi dokumen/literatur dan interpretasi peta serta citra satelit.

Teknik analisis yang digunakan dalam penelitian ini secara garis besar menggunakan analisis secara deskriptif kuantitatif dan skoring. Penelitian ini merupakan penelitian studi kasus dengan metode observasi langsung ke lapangan kemudian diproses menggunakan analisis deskriptif kuantitatif dan skoring. Analisis yang digunakan terdiri dari tiga tahapan yaitu: (1) Analisis Keterpaduan Komponen Pariwisata untuk mengetahui keterpaduan antar komponen pariwisata dengan teknik analisis deskriptif kuantitatif dan skoring; (2) Analisis Keberlanjutan Kawasan Pariwisata untuk mengetahui keberlanjutan kawasan sebagai kawasan wisata dengan teknik analisis deskriptif kuantitatif dan skoring; (3) Analisis Keterpaduan Pariwisata yang Berkelanjutan untuk mengetahui keterpaduan komponen pariwisata sebagai kawasan wisata budaya yang berkelanjutan dengan teknik analisis deskriptif crosstab.

\section{HASIL DAN PEMBAHASAN}

Analisis Tingkat keterpaduan komponen pengembangan pariwisata dapat dilihat melalui beberapa indikator diantaranya koordinasi/kerjasama antar stakeholder, dukungan layanan pariwisata, proses investasi kegiatan pariwisata.Dari hasil analisis diketahui bahwa komponen pengembangan pariwisata yang terdapat di Kawasan Kotagede dinilai memenuhi kriteria terpadu. Diantara keempat komponen tersebut terdapat satu komponen yang menunjukkan kelemahan dalam mendukung berjalannya kegiatan wisata, yaitu aksesibilitas.

Penilaian terhadap aksesibilitas berdasarkan pada kemudahan pencapaian dilihat dari kondisi jalan dan jarak dari/ke daya tarik wisata (atraksi) dengan nodal trasnportasi terdekat. Komponen tersebut dianggap belum mampu mendukung berjalannya kegiatan wisata secara optimal karena dalam pencapaiannya termasuk dalam klasifikasi sulit dan jarak. Sehingga hal tersebut menunjukkan bahwa komponen pengembangan pariwisata di Kawasan Kotagede meskipun telah menunjukkan terpadu, namun tingkat keterpaduannya lemah.

Dari analisis ketiga komponen pariwisata berkelanjutan yaitu ekologis, ekonomis, dan sosal budaya diketahui bahwa maka keberlajutan Kawasan Kotagede sebagai kawasan wisata budaya telah menujukkan keberlanjutan, meskipun terdapat kelemahan dalam aspek ekonomi yang dinilai belum mampu mendukung keberlanjutan kawasan sebagai kawasan wisata budaya.

Berlanjut secara ekonomi dalam kegiatan kepariwisataan berarti tidak hanya mengambil keuntungan dari kawasan potensial tersebut, namun juga memberikan manfaat ekonomis bagi masyarakat lokal. Manfaat tersebut antara lain yaitu adanya peningkatan pendapatan dan terbukanya peluang usaha atau kesempatan kerja yang bertujuan meningkatkan kesejahteraan.

Kotagede sebagai kawasan wisata telah mampu membuka peluang usaha maupun memberikan kesempatan kerja, namun belum mampu meningkatkan kesejahteraan masyarakat. Hal tersebut menunjukkan bahwa komponen pengembangan pariwisata yang terdapat di Kawasan Kotagede meskipun telah menunjukkan mampu berlanjut, namun tingkat keberlanjutannya lemah.

Setelah melakukan dua analisis sebelumnya, kemudian dilanjutkan analisis terpadu yang berkelanjutan untuk mengetahui bagaimanakahtingkat keterpaduan dalam komponen pengembangan pariwisata di Kawasan 
NirmanaAdheliadkk, KeterpaduanKotagede...

Kotagede sebagai kawasan wisata budaya yang berkelanjutan.

Kawasan Kotagede dinilai telah memenuhi kriteria sebagai kawasan wisata budaya yang berkelanjutan dengan komponen pengembangan pariwisata yang terpadu. Namun, dalam keterpaduan yang berkelanjutan tersebut masih terdapat beberapa komponen dan aspek yang belum memenuhi kriteria diantaranya aksesibilitas dan keberlanjutan ekonomis yang ditunjukkan dengan skor terendah.

Aksesibilitas yang dimaksud dalam hal ini adalah jarak menuju objek wisata dilihat berdasarkan titik transportasi terdekat, dimana menujukkan pencapaian yang sulit. Sedangkan keberlajutan ekonomi dinilai belum menujukkan keberlajutan dikarenakan keberadaan kegiatan wisata yang ada belum mampu memberikan manfaat secara ekonomis bagi masyarakat Kotagede.

Apabila dilihat berdasarkan teori yang dikemukakan oleh Inskeep dan Gunn (dalam Permana, 2009:7), hasil analisis tersebut sesuai dengan aspek yang mendukung pengembangan pariwisata.

mempertahankan

Kemampuan kelestarian lingkungan ditunjukkan dengan skor yang tinggi antara komponen atraksi, ekologi dan sosial budaya. Keberadaan daya tarik wisata menjadi salah satu hal penting yang mempengaruhi kelestarian lingkungan yaitu dengan cara melindungi, mengembangkan, dan memanfaatkan. Secara tidak langsung, keberadaan daya tarik wisata ini telah memanfaatkan potensi kawasan yang ada, yaitu sejarah dan budaya yang dikembangkan melalui kegiatan wisata. $\mathrm{Hal}$ tersebut dilakukan dengan meningkatkan kualitas lingkungan guna menarik wisatawan, dengan demikian akan terjaga kelestarian lingkungannya. Upaya konservasi dan pelestarian kawasan serta partisipasi masyarakat yang tinggi dalam menjaga dan mempertahankan seni budaya yang ada merupakan salah satu bentuk perlindungan terhadap sumber daya budaya.

Aspek selanjutnya yaitu mengenai tingkat kesejahteraan masyarakat. Berdasarkan hasil analisis diketahui bahwa meskipun kegiatan wisata di Kawasan Kotagede membuka peluang usaha dan meningkatkan pendapatan, namun hal tersebut belum mampu meningkatkan kesejahteraan masyarakatnya. Sedangkan apabila dilihat berdasarkan kepuasan pengunjung, hal tersebut dinilai masih rendah, dikarenakan aksesibilitas yang lemah sebagai penunjang berjalannya kegiatan pariwisata di kawasan tersebut.

Selain itu, keterpaduan yang berkelanjutan ini juga ditinjau dengan keterpaduan yang ditunjukkan oleh aktor pengembangan pariwisata (stakeholder). Apabila dilihat dari kerjasama yang dilakukan antar stakeholder, berdasarkan hasil wawancara masih terdapat kekurangan antara pemangku kepentingan. Baik dari sisi pemerintahan sendiri yang mencakup Pemerintah Kota Yogyakarta, Pemerintah Kabupaten Bantul, dan Pemerintah D.I. Yogyakarta yang masih menunjukkan kinerja yang kurang terkoordinasi dengan baik. Dari sisi masyarakat merasa bahwa pemerintah belum melakukan tugas dan fungsinya sebagai fasilitator secara maksimal, sehingga diperlukan mitra yang selaras antar stakeholder yang terlibat.

Kawasan wisata budaya Kotagede ini telah memenuhi dua prinsip yang ditunjukkan dengan partisipasi atau keikutsertaan masyarakat dalam pengelolaan kawasan wisata. Namun, dalam prinsip sumber daya manusia dan pengendalian dinilai belummaksimal dikarenakan kurang terkoordinasinya kinerja stakeholder terkait. Oleh karena itu, meskipun komponen pengembangan pariwisata Kawasan 
Kotagede menunjukkan keterpaduan yang keberlanjutan, tetapi hubungan yang dihasilkan tersebut masih lemah.

\section{KESIMPULAN}

Berdasarkan hasil penelitian yang telah dilakukan dan pembahasan berdasarkan teori dikemukakan oleh Inskeep dan Gunn (dalam Permana, 2009:7), diketahui bahwa keterpaduan komponen pengembangan pariwisata di Kawasan Kotagede menunjukkan berkelanjutan sebagai kawasan wisata budaya. Selain melalui keterpaduan antar komponen pengembangan dan prinsip pariwisata berkelajutan, hal tersebut juga dilihat berdasarkan kerjasama yang dilakukan oleh stakeholder terkait.

Berdasarkan sasaran yang akan dicapai pada awal penelitian, kawasan wisata budaya ditinjau dari komponen pengembangan pariwisata yaitu atraksi, aksesibilitas, amenitas dan ancillary services. Sasaran selanjutanya yaitu mengenai keterpaduan antar komponen yang membentuk kawasan wisata dengan hasil menunjukkan terpadu meskipun komponen aksesibilitas dinilai belum mampu mendukung berjalannya kegiatan wisata di Kotagede. Kemudian sasaran berikutnya yaitu keberlanjutan kawasan menunjukkan mampu berkelanjutan meskipun aspek ekonomi dinilai masih lemah.

Sasaran terakhir yaitu untuk mengetahui keterpaduan komponen pengembangan pariwisata yang berkelanjutan sebagai kawasan wisata budaya, didapatkan hasil bahwa keduanya menunjukkan nilai yang baik, yaitu komponen pengembangan pariwisata menunjukkan keterpaduan yang mampu berkelanjutan sebagai kawasan wisata budaya.

Setelah didapatkan hasil tersebut, kemudian dilihat pula berdasarkan keterpaduan aktor pengembangan pariwisata. Dari hasil analisis didapatkan bahwa stakeholder terkait belum mampu menunjukkan kerjasama yang baik dalam mendukung berjalannya kegiatan wisata di Kawasan Kotagede. Didapatkan bahwa masyarakat Kotagede telah ikut berpartisi dan berperan aktif dalam kegiatan wisata, namun perhatian dari pemerintah dan swasta dinilai masih kurangberpengaruh dalam pengembangannya.

\section{REFERENSI}

Creswell, John. 2010. Research Design Pendekatan Kualitatif, kuantitatif dan Mixed. Yogyakarta: Pustaka Pelajar

Inskeep, E. (1991). Tourism Planning: An Integrated and Sustainable Development Approach. Van Nostrand Reinhold, New York.

Permana, E.(2009).Integrasi Pengembangan Wisata Pantai dan Permukiman Nelayan di Pesisir Barat Kabupaten Bengkulu Selatan Dalam Rangka Konservasi Alam.Tesis Magister Arsitektur Bidang Keahlian Perumahan dan Permukiman, Institut Teknologi Sepuluh Nopember, Surabaya. 